\title{
The factors affecting restaurant customers' return intention after online group buying promotion
}

\author{
Yao Chen \\ Key laboratory of Behavioral Science, Institute of \\ Psychology \\ Chinese Academy of Sciences \\ University of China Academy of Sciences \\ Beijing, PR China \\ e-mail: cyshenshuo@163.com
}

\author{
Yiwen Chen \\ Key laboratory of Behavioral Science, Institute of \\ Psychology \\ Chinese Academy of Sciences \\ Beijing, PR China \\ e-mail: chenyw@psych.ac.cn
}

\author{
Xin Li \\ Key laboratory of Behavioral Science, Institute of Psychology \\ Chinese Academy of Sciences \\ University of China Academy of Sciences \\ Beijing, PR China \\ e-mail: xinli@psych.ac.cn
}

\begin{abstract}
With the expansion of online group buying, this new promotion model is used by more and more restaurants. However, it is difficult for restaurant owners to make profit from one time online group buying promotion; they are expecting that customers brought by online group buying could return and become their long-term customers. This study adopts both correlation analysis and structural equation modeling to analyze the factors affecting restaurant customers' return intention after online group buying promotion and finds that perceived quality, perceived value and customer satisfaction would greatly affect customers' return intention. Perceived value and customer satisfaction are also mediating variables in our study model. This study also finds that the deeper discount restaurants offer, the less likely the customer would return to consume at the original price without discount.
\end{abstract}

Keywords-online group buying; return intention; customer satisfaction; perceived value.

\section{INTRODUCTION}

Online group buying refers to a certain number of consumers join together as a group through internet with the purpose of buying a certain product with a discount [1]. Since GROUPON (an American group buying website) started in 2008, online group buying has spread all over the world. Such new business model is welcomed by both consumers and business owners. In the $1^{\text {st }}$ half of 2013, the total sales amount of online group buying in China reached RMB 23.89 billion, and the quantity of its customers was over 100 million, every day, there are 37 million people attending online group buying. Among all kinds of products published on group buying websites in China, catering accounts for $54.8 \%$ [2]. Online group buying dose bring a lot of new customers to the restaurants, it offers deep discount and the customers have to be a group instead of an individual, from the prospect of psychology, deep discount could lower the customer's perceived risk to try a new product $[2,4]$ and group buying could induce conformity behavior [5 10], thus, these two factors help online group buying to attract new customers. However, due to the deep discount, it is difficult for the restaurant owners to make profit from one single group buying consuming. According to Dholakia's research, $32 \%$ of business owners reported unprofitable during online group buying promotion [11]. To earn more profit, the restaurant owners will have to rely on customer's repurchase behavior after the online group buying promotion. But from the current studies, it seems the repurchase rate after the online group buying experience is not optimistic. Dholakia's investigation shows that less than $15 \%$ of group buying customers are willing to come back to the restaurant to repurchase product or service at the original price [11]; Tuten and Ashley's report also shows that repurchase behavior only occurs on less than $30 \%$ of the group buying customers [4]. Fei reports that the customers of GROUPON are less likely to repurchase the product or service bought through GROUPON than the consumers of OPENTABLE-an American website who offers restaurant reservation service without discount [12]. Therefore, this study would like to discuss the factors affecting restaurant customer's return intention after online group buying promotion, aiming at assisting the restaurant owners to know better about the customers brought by online group buying so they could improve the service specifically.

\section{LITERATURE REVIEW}

Studies on repurchase behavior advise that customer satisfaction is the main factor that affects consumers' repurchase behavior, high levels of satisfaction would result in increased loyalty and future visitation [6, 13 14]. The improvement of satisfaction has a positive effect on the repurchase intention of group buying customers [6]. In Han and Ryub's report [14], $50.6 \%$ of the participants report that satisfaction is the reason for their repurchase behavior. In addition to customer satisfaction, perceived quality which refers to product, physical environment, and employee service also effects on the repurchase intention and satisfaction of group buying customers [6]. 


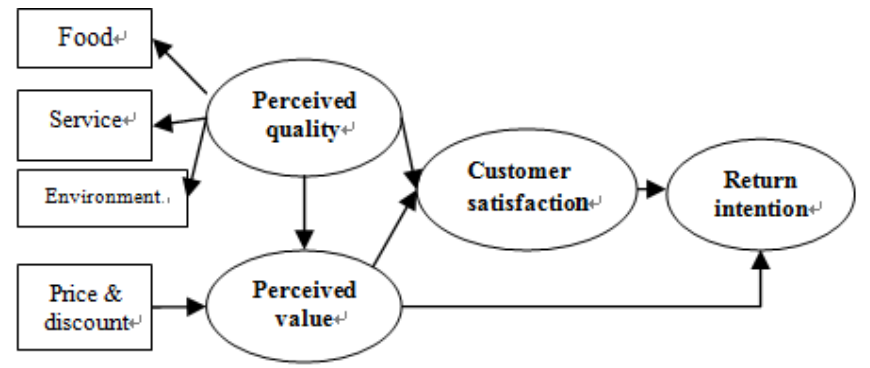

Figure 1 Factors affecting restaurant customers' return intention

Sometimes even the customers are satisfied with the offered products and service, they don't come back either. Researchers find that there is another factor which will affect repurchase behavior - the perceived value [15 16]. Discount is the major characteristic of online group buying. Consumers would purchase products or service at very low price with deep discount through group buying websites. According to the reference price theory, the price specially offered for online group buying would become consumers' reference price when they are about to purchase the same product or service later on. Therefore, the customers would think original price without discount is not a reasonable price to accept [15]. This explanation consists with Kotler's perspective for sales promotion [17] that continuous sales promotions may reduce the value of the product or service in the consumers' mind.

Based on the above we hypothesize as follows and the study model is presented as Fig. 1:

H1. The perceived quality has positive correlation with customer satisfaction.

H2. The perceived value has positive correlation with customer satisfaction.

H3. The customer satisfaction has positive correlation with customer return intention.

H4. The perceived value has positive correlation with customer's return intention when restaurants offer the same discount as online group buying.

H5. The discount rate of online group buying has negative correlation with customer's return intention when the restaurants offer no discount. That is, the deeper discount the restaurants offer for online group buying promotion, the less likely the customer would return to consume at the original price without discount.

H6. Perceived value is the mediating variable between perceived quality and customer satisfaction.

H7. Perceived value is the mediating variable between perceived quality and return intention.

H8. Customer satisfaction is the mediating variable between perceived value and return intention.

H9. Customer satisfaction is the mediating variable between perceived quality and return intention.

\section{METHOD AND RESULTS}

\section{A. Measurement}

The measurement tool of this study is questionnaire. The questionnaire mainly refers to the questionnaire of RYU \& Han (2010) [14] and Kim et al. (2008) [18], and is modified to better suit for online group buying. It includes 5 parts. Part 1 is about perceived service quality which is described in 3 dimensions: food quality, restaurant environment and the restaurant employees' service performance; part 2 is about the perceived value; part 3 is about the customers' overall satisfaction about the consuming experience; part 4 is about the return intention. All the four parts are using 5-ponit Likert scale, the descriptors ranged from "strongly disagree" to "strongly agree". All the Cronbach's Alpha coefficients of each dimension are over 0.70 (Table 1). The last part is about demography.

\section{B. Data collection}

Data is collected via questionnaire published on line. Participants who did not attend any online group buying for catering would be refused to continue to fill the questionnaire automatically.

The questionnaire is pilot tested by 22 participants including students in the institute of Psychology and white collar. Necessary changes are made to improve the questionnaire after the pilot test. The formal questionnaire is then published on the internet for 4 weeks. Total 312 questionnaires are collected, among which, 300 copies are valid, yielding the fully complete rate $96.15 \%$. The Cronbach's Alpha coefficient is 0.913, suggesting the reliability of this questionnaire is fine.

\section{Data analysis and result}

The hypothesis is analyzed using SPSS19.0 and AMOS 21.0. The statistical analysis is as follows: (1) correlation analysis on all measures; (2) structural equation modeling analyzes the relationship of all factors and verifies the study model (Fig.1).

The 300 participants are from 25 provinces in China, $61 \%$ are female and 39\% are male. The married account for $70 \%$. Participants aged from 26 to 35 account for $78.7 \%$; there is no teenage who are younger than $18.80 \%$ of the participants are undergraduates. $64.3 \%$ are with income RMB3001 to 8000.

Mean, standard deviation, and correlation of all variables are presented in table 1, the three dimensions (food, environment and employee service) of perceived quality are inter-correlated with each other and are strongly correlated

TABLE I. MEAN, STANDARD DEVIATION, AND INTERCORRELATIONS OF ALL MEASURES $(\mathrm{N}=300)$

\begin{tabular}{lcccccccc}
\hline & $\alpha$ & $\mathrm{M}$ & $\mathrm{SD}$ & 1 & 2 & 3 & 4 & 5 \\
\hline $\begin{array}{l}\text { 1 Service quality } \\
\text { 2 Food quality }\end{array}$ & 0.84 & 3.75 & 0.75 & & & & & \\
$\begin{array}{l}\text { 3 Restaurant } \\
\text { environment }\end{array}$ & 0.77 & 3.95 & 0.51 & $.63^{* *}$ & & & & \\
$\begin{array}{l}\text { 4 Perceived } \\
\begin{array}{l}\text { Value } \\
\text { 5 Customer }\end{array}\end{array}$ & 0.75 & 4.02 & 0.57 & $.62^{* *}$ & $.56^{* *}$ & & & \\
$\begin{array}{l}\text { satisfaction } \\
\begin{array}{l}\text { R Return } \\
\text { intention }\end{array}\end{array}$ & 0.80 & 4.04 & 0.63 & $.55^{* *}$ & $.69 * *$ & $.63^{* *}$ & $.79 * *$ & \\
\hline & 0.76 & 3.52 & 0.87 & $.60^{* *}$ & $.64 * *$ & $.48^{* *}$ & $.70^{* *}$ & $.65^{* *}$ \\
\hline
\end{tabular}


with customer satisfaction, $\mathrm{H} 1$ is supported. The perceived value has significant positive correlation with customer satisfaction too $(r=0.79 \mathrm{p}<0.001), \mathrm{H} 2$ is supported. The customer satisfaction has significant positive correlation with customer return intention, $\mathrm{H} 3$ is supported.

The perceived value has positive correlation with customer's return intention when restaurants offer the same discount as online group buying $(r=0.59 \mathrm{p}<0.001)$, $\mathrm{H} 4$ is supported.

The Pearson correlation coefficient of discount rate (high to low) and the return intention without discount is 0.13 ( $\mathrm{p}<0.05)$, H5 is supported, that is, the deeper discount the restaurants offer for online group buying promotion, the less likely the customer would return to consume at the original price without discount.

The structural equation modeling results are presented in Fig. 2. All path coefficients are significant. GFI is 0.997 and AGFI is 0.964 , both of them are greater than 0.90; RMSEA is $0.044, \chi^{2}=3.152\left(\mathrm{p}=0.207, \mathrm{df}=2, \chi^{2} / \mathrm{df}=1.576\right.$. All of these indexes suggest that the study model well fit the data collected.

Path analysis shows that:

1). Perceived value plays a completely mediating role between perceived service quality and customer satisfaction. So when the customer doesn't receive good service, he or she would think the expense is not worthy enough, and it would eventually affect their satisfaction about the restaurant.

2). Perceived value plays a partially mediating role between perceived food quality and customer satisfaction.

3). Perceived value plays a partially mediating role between perceived environment quality and customer satisfaction.

H6 is supported.

4). Perceived value plays a partially mediating role between perceived service quality and return intention.

5). Perceived value plays a partially mediating role between perceived food quality and return intention.

6). Perceived value plays a completely mediating role between perceived environment quality and return intention.

H7 is supported.

7). Customer satisfaction plays a partially mediating role between perceived value and return intention.

H8 is supported.

8). Customer satisfaction plays a partially mediating role between perceived food quality and return intention.

9). Customer satisfaction plays a completely mediating role between perceived environment quality and return intention.

H9 is supported.

\section{DISCUSSION AND CONCLUSION}

Customer satisfaction is a key factor to keep customers; as customer satisfaction is the mediator of the 3 dimensions (food, service and environment) of perceived quality and return intention, improvement on these three dimensions would increase customer satisfaction and eventually enhance return intention. All the 3 dimensions of perceived quality are remarkably inter-correlated with each other and strongly correlated with customer satisfaction, among which, food has the highest correlation coefficient $(r=0.69 \mathrm{p}<0.001)$, it suggests food is still the root of a restaurant, restaurants should firstly focus on food quality such as food taste, freshness, nutrition and variety in order to improve customer satisfaction. Restaurant environment is the $2^{\text {nd }}$ important factor to affect customer satisfaction $((\mathrm{r}=0.63 \mathrm{p}<0.001)$. With the improvement of people's living standard, customers would care more about the dinning environment. So besides cleanness, restaurant owners should try to provide their customers with comfortable and relax environment. Employee service turns out to be the least important factor to affect customers satisfaction $(r=0.55 \mathrm{p}<0.001)$. Maybe it is because customers don't expect restaurants to offer excellent service to them at such deep discount. It seems differential treatment on online group buying customers is common in catering industry. And the result could be different when we study non group buying. However, service quality is still important to customers satisfaction, if the restaurant employees are friendly and willing to help, and customers are treated well, they would be more satisfied and would more likely to repurchase.

Perceived value is the key factor to affect customer satisfaction and their return intention. Since online group buying offers deep discount, it would make the perceived value greater than the same food severed at original price, therefore we could see that customer would think the online group buying offer is reasonable and they would like to return when the restaurant offers similar discount. However, when the restaurant offers no discount, the customers are less

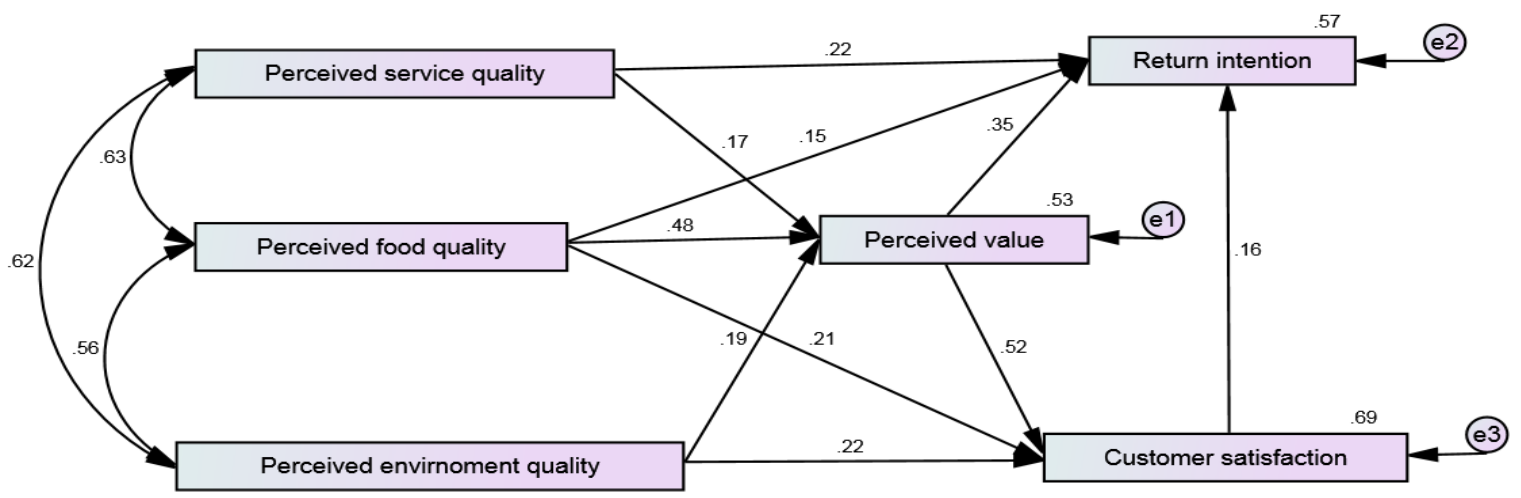

Fig. 2 Factor analysis with path diagram 
likely to return to consume at the original price, moreover the deeper the discount offered by online group buying, the less likely the customers would like to accept the original price. Our result is consistent with the theory of Zhong, Tan \& Lvovskaya [15] and Kotler [17] that customers would take the discounted price as reference price to judge the original price. It suggests that restaurant owners should consider well about the discount rate they would offer through online group website, as deeper discount may result in lower return rate.

Among 300 participants, female accounts for $61 \%$, the married accounts for $70 \%$, it is consistent with the traditional view that female or married people would be more economical than male or single person, online group buying with deep discount is good choice for them to dine outside. $64.3 \%$ of the participants are with median income ranged from RMB3001-8000, discount is attractive to them when dinning outside.

Participants aged from 26 to 35 accounts for $78.7 \%$, it suggests that the main customers of online group buying are young people. There are some restaurants with theme of "memory for the 80's" or "for the youth", online group buying would be able to bring target customers for them.

$80 \%$ of the participants are undergraduate, it suggests that the main customers of online group buying are well educated, it may be because of the customers of online group buying should know well about computer and E-bank.

Overall, customer would expect high quality food at reasonable price. When making strategy for online group buying, restaurant owners should take into account that their target customers consist of young, married female who are well educated with median income. If your target customers are old people, teenage or your target market is high-end, online group buying may be not good enough for you. And again, please keep in mind that the deepest discount is not always the best choice, a reasonable discount rate could help restaurant owners to attract new customers along with to win greater return rate.

The limitation of the study is that we only study customers' return intention after online group buying, though return intention is the most important factor to affect customers' repurchase behaviors, it could not completely explain the actual repurchase behavior. Future study could try to adopt longitudinal research to follow up with participants months later to find out the difference between return intention and repurchase behavior.

\section{ACKNOWLEDGMENT}

This study is founded by the National Natural Science Foundation of China (No.71171188). The corresponding author is Yiwen Chen. His profession and rigorous scholarship inspired us. This thesis could not be completed without his continuous encouragement and guidance. The available e-mail of the corresponding author is chenyw@psych.ac.cn.

\section{REFERENCES}

[1] $\mathrm{H}-\mathrm{H}$ Cheng and S-W Huang, "Exploring antecedents and consequence of online group-buying intention: An extended perspective on theory of planned behavior", International Journal of Information Management 33, 2013 185- 198

[2] The marketing date of China online group buying - the 1st half of 2013

[3] U.M. Dholakia, "What makes Groupon promotions profitable For businesses," Rice University, 2011.

[4] T.L. Tuten and C. Ashley, "Promotional strategies for small businesses," Small business institute, vol. 7, no. 2, 2011, pp. 15-29.

[5] W.-Y. Chen and P.-H. Wu, "Factors affecting consumers' motivation in online group buying customers," 2010 sixth international conference on intelligent information hiding and multimedia signal processing, 2010, October, pp. 708-711.

[6] Z. Zhang, Z. Zhang, F. Wang, R. Law and D. LI, "Factors influencing the effectiveness of online group buying in the restaurant industry," International Journal of Hospitality Management, vol. 35, 2013, pp. 237-245; DOI 10.1016/j.ijhm.2013.06.012.

[7] Z.M. Luo., "Psychology of Consumer," Bejing: Tsinghua University Press, Jan. 2007.

[8] C.-H. Yang, W.-P. Lien and C.-H. Li, "The relationships among conformity, information richness and purchase intention in group buying," 2013 International Conference on Business and Information 2013, July, pp. 622-628.

[9] X.F. Gao., "A study on Online Group-buying conformity," Beijing University of Posts and Telecommunications., 2011.

[10] C.-L. Tai, J.-Y Hong,C.-M. Chang, and L.-C.Chen, "Determinants of consumer's intention to participate in group buying," Social and Behavioral Sciences, vol. 57, 2012, pp. 396-403; DOI 10.1016/j.sbspro.2012.09.1203.

[11] U.M. Dholakia, "How effective are Groupon promotions for businesses," Rice University, 2010.

[12] B. Fei, "Study of China's online catering market under the booming of online group purchasing," Master thesis. University of Nevada., 2010

[13] W.-L. Shiau and M.M. Luo, "Factors affecting online group buying intention and satisfaction: A social exchange theory perspective," Computers in Human Behavior, vol. 28, no. 6, 2012, pp. 2431-2444; DOI 10.1016/j.chb.2012.07.030.

[14] H. Han and K. Ryu, "The theory of repurchase decision-making (TRD): Identifying the critical factors in the post-purchase decisionmaking process," International Journal of Hospitality Management, vol. 31, no. 3, 2012, pp. 786-797; DOI 10.1016/j.ijhm.2011.09.015

[15] C. Zhong, S.Tan, and Y.Lvovskaya, "Online discount coupon promotions and repurchasing behaviors : the Groupon case," School of Sustainable Development Society and Technolog., 2012.

[16] L.-Y. Wu, K.-Y. Chen, P.-Y. Chen and S.-L. Chen, "Perceived value, transaction cost, and repurchase-intention in online shopping: A relational exchange perspective," Journal of Business Research, vol. 67, no. 1, 2014, pp. 2768-2776; DOI 10.1016/j.jbusres.2012.09.007.

[17] P. Kotler, "Marketing Management," China Renmin University Press APR. 2012

[18] Kim, W.G., Ng, C.Y.N., and Kim, Y.-s.: 'Influence of institutional DINESERV on customer satisfaction, return intention, and word-ofmouth', International Journal of Hospitality Management, 2009, 28, (1), pp. 10-17. 